Studia nad Autorytaryzmem i Totalitaryzmem 43, nr 1

Wrocław 2021

https://doi.org/10.19195/2300-7249.43.1.4

ADAM WIELOMSKI

ORCID: 0000-0001-8692-6469

Uniwersytet Kardynała Stefana Wyszyńskiego

a.wielomski@uksw.edu.pl

\title{
National sovereignty in the political doctrine of Front National/Rassemblement National
}

\begin{abstract}
The État-nation (Nation-State) doctrine is the main ideology of the French Revolution and subsequent revolutionary tradition, but the contemporary French left and liberal centre are pro-Europeans and hostiles to idea of Nation-State. The whole spectrum of French political elite reject the idea of nation and Nation-State as "reactionary" and "undemocratic". In France, the idea of État-nation is defended by the nationalist right only, symbolised by the Le Pen's family. The purpose of this text is to present this genetically-leftist idea as the programme of the political right.
\end{abstract}

Keywords: Jean-Marie Le Pen, Marine Le Pen, Front National, Rassemblement National, nationalism.

\section{The position of France and the French people towards European integration}

For a long time, France was reluctant to support the integration processes in Europe. During the decade of Charles de Gaulle's rule (1958-1969), Paris proclaimed the idea of a 'Europe of Homelands', a formulation of a loose confederation of sovereign states. ${ }^{1}$ It was only after his departure that France opted for European integration. The Gaullists themselves supported this position only years later, during the presidency of Jacques Chirac (1995-2007). Currently, the parties

1 J. Vernant, "Le Général de Gaulle et la politique extérieure”, Politique Étrangère 35, 1970, no. 6, pp. 619-629; A. Hall, Naród i państwo w myśli politycznej Charles'a de Gaulle'a, Warszawa 2005 , pp. $439-516$. 
which have hitherto dominated the political scene of the Fifth Republic want to accelerate integration. The Eurosceptic trend and the defense of the nation-state are represented today by the Front National, in 2018 renamed the Rassemblement National (hereinafter: FN/RN).

In general, there exists a consensus in France that Europe is facing a choice: either accelerating integration and establishing a 'European state', or undoing the process and restituting the nation-state. The current intermediate state of affairs does not satisfy anyone, because it stems from the contradictions between the advanced processes of economic integration, forcing the creation of a European federation, and the strong sense of pride of national sovereignty, the lack of social identification with the abstraction of the 'European state' and the lack of the European nation as a carrier of sovereignty in a futuristic super-state. Over $80 \%$ of French people reject the idea of a 'European nation' devoid of a common language and history and do not want see a 'European president' being instituted. Even the French voting for pro-European parties complain about the 'democratic deficit' and 'oligarchy' in EU institutions. ${ }^{2}$

The FN/RN agenda, especially its Euroscepticism, is often referred to as 'populist' and devoid of arguments. The purpose of this text is a polemic with this stereotype. In official policy papers and in the public commentary of the FN/RN leadership ${ }^{3}$ directed against the politicians ruling the country, the sovereignty of

2 J. Riva, La difficile cohabitation Etats-Nations/Europe, Paris 2013.

3 An important note: the FN/RN community currently does not issue policy papers. This presents a difficulty for the researcher, because he must decide which of the leaders' statements are statements on behalf of the party, and which are private views. The same applies to political journalism and theoretical dissertations. This problem did not exist in the nineties, when an official party publishing house existed, Éditions Nationales in Saint-Cloud near Paris, whose books expressed the official views of the FN. These were detailed studies containing a specific political philosophy, not interviews or short journalistic texts. That is why we decided to base this text mainly on works published at that time. Observing the speeches of contemporary FN/RN leaders, we do not see significant differences with the party doctrine formed at that time. Activists of this party, however, do point to one change that appeared when Marine Le Pen was chairman, namely the departure of the party from Catholic demands: see: “Oskarżenia o faszyzm to oczywiście tradycyjny repertuar lewicy'. Z Bernardem Anthonym rozmawia Adam Wielomski”, Pro Fide, Rege et Lege 92, 2008, no. 1. External observers point to the following: 1 . they confirm the final detachment of the national idea from Catholicism in favor of purely political nationalism; 2 . recognition of women's right to abortion; 3. consent to same-sex partnerships (including admission of homosexuals as party candidates); 4 . in connection with doubling of the party's electoral base at the expense of left-wing parties, moving away from liberal economic concepts towards social demands; and 5. change of the party's social image, for example, by departing from any anti-Jewish themes. See: J. Díaz Nieva and J.L. Orella Martínez, De Le Pen a Le Pen. El Front National camino al Elíseo, Madrid 2015, pp. 151-162. These changes were announced by Marine Le Pen in her policy work $\dot{A}$ contre flots, Paris 2006, pp. 283-306. Their culmination was the removal of JeanMarie Le Pen from the ranks of the party and changing its name, which was a symbolic dissociation from the old party program as part of the FN's 'de-diabolization' process. See: D. Albertini, D. Doucet, Histoire du Front national, Paris 2014, pp. 350-355. In particular, it was about cutting

Studia nad Autorytaryzmem i Totalitaryzmem 43, nr 1, 2021

(C) for this edition by CNS 
the French people (souverainete du peuple) is constantly invoked. The nation is an absolute sovereign in internal and external relations. This problem has a strong historical foundation, and without its presentation, it is impossible to understand the nature of Euroscepticism on the Seine.

\section{The historical background of 'État-Nation'}

The French consider themselves to be the oldest nation in Europe, and historians date France's rise to the Hundred Years War with England (1337-1453). ${ }^{4}$ The French were conscious of their own identity when other nations existed only as ethnic groups, loyal to the king and dynasty, but not their homeland and nation. The French also became the first modern European civic nation, based on the principle of national sovereignty, which occurred during the French Revolution (17891815). ${ }^{5}$ At the time, a model of the nation-state and the nation itself was formed, in which the doctrine of the primordial and inalienable sovereignty of the people (peuple), taken from Jean-Jacques Rousseau, was identified with the sovereignty of the nation (Nation). ${ }^{6}$ A sovereign people/nation has the power to do everything it wants within its domain. Its will is not limited by the law of nature, nor by the constitution, nor by the separation of powers. ${ }^{7}$ This nationalism is connected to the idea of a civic, rather than ethnic, community. A Frenchman is a French citizen, regardless of race, nationality or the ethnic group to which he belongs. This applies also to a naturalized foreigner. At the same time, Francophones born and residing in Quebec, Switzerland, Luxembourg and Belgium (Wallons) are not considered Frenchmen. ${ }^{8}$ Francophones from outside France are not part of the political nation, because in 1789, the ancestors of modern Frenchmen established a social

the party off from the famous statement by Le Pen-father about gas chambers being a 'historical detail' (détail de l'histoire), ibidem, pp. 141-142.

4 M.M. Martin, Histoire de l'unité française, Paris 1957, pp. 163-181; C. Beaune, Naissance de la nation France, Paris 1985; J. de Viguerie, Les deux patries. Essai historique sur l'idée patrie en France, 2003, pp. 18-19.

${ }^{5}$ H. Kohn, Prelude to Nation-States. French and German Experiences, 1789-1815, Princeton 1967, pp. 7-118; J. Plumyène, Les nations romantiques. Histoire du nationalisme. Le XIXe siècle, Paris 1979, pp. 21-80; A. Wielomski, Nacjonalizm francuski 1886-1940. Geneza, przemiany i istota filozofii politycznej, Warszawa 2007, pp. 27-130.

6 J. Guilhaumou, "Rousseau, citoyenneté, et la Révolution française (1789-1792)”, Etudes Jean-Jacques Rousseau 5, 1989, no. 3, pp. 5-26; X. Palacios, "Le concept de Nation chez JeanJacques", [in:] Jean-Jacques Rousseau. Politique et Nation, ed. R. Thiéry, Paris 2001, pp. 2738; M. Neumann, Neumann M., "Rousseau et le nationalisme", [in:] Jean-Jacques Rousseau..., pp. 343-349.

7 J.J. Rousseau, Du contrat social, Paris 2008 [1762], II, 1-3.

8 R. Brubaker, Citizenship and Nationhood in France and Germany, Cambridge, MA 1996, pp. 85-91; R. Girardet, Nationalismes et Nation, Paris 1996, pp. 15-16. 
agreement on the creation of a new France, thus breaking with the Catholic-monarchical tradition.

Francophones from Quebec, Switzerland, Luxembourg and Belgium did not participate in this act, being subjects/citizens of other states. Their descendants can individually apply for French citizenship, thus accepting the state founded in 1789 and based on the sovereignty of the nation, but they are not automatically part of it simply because of linguistic unity and a shared culture. Nation and citizenship are one and the same. The French nation-state (État-Nation) is a civic community formed from a social contract. The concept of the nation derives from the traditions of the French Revolution and the thought of Rousseau. The État-Nation doctrine consists of three ideas: ${ }^{9}$

1. 'We are the state'. A sovereign nation expresses its will by means of a state, in which, in 1789, the sovereignty established by Louis XIV was taken away from Louis XVI by the Nation. A new sovereign emerged. The essence of the political revolution of 1789 was the transfer of the 'I am the state' (l'État c'est moi) formula, assigned to Louis XIV, to a new sovereign. It is now the people who proclaim the formula 'the state is the nation' (État-Nation) ${ }^{10}$

2. External sovereignty. Established in 1789, the sovereign État-Nation is not subject to anyone in international relations and does not recognize any external political power or any doctrinal or ideological authority. It does not recognize the authority of Rome over the Catholic Church and the emperor or other universal authority in political matters. This is also consistent with Rousseau's view, according to which the state ruled by the people was considered sovereign and the only legal entity in international relations. ${ }^{11}$

3. Internal sovereignty. A sovereign nation does not recognize ethnic and regional mosaics in its interior. Within the state, there must exist a uniform nation with a uniform culture, having one political will, imitating the unity of the monarch's will (Rousseau's volonté générale). The state is 'one and indivisible' (Republique une et indivisible). This nationalism prefers centralization and abolishes all ethnic and regional differences. The nation is homogeneous. It does not tolerate privileged social groups stemming from legal (class position) and political status. It also does not tolerate linguistic differences, privileges based on confession, eth-

9 A. Wielomski, "État-Nation. O specyfice francuskiego rozumienia narodu", Pro Fide Rege et Lege 79, 2018, no. 1, pp. 214-270.

10 J.J. Chevallier, "Jean-Jacques Rousseau ou l'absolutisme de la volonté générale", Revue Française de Science Politique 18, 1953, no. 1, pp. 18-19; J.P. Kutz, Gemeinwille oder Gotteswille? Jean-Jacques Rousseau und Joseph de Maistre über Souveränität und Staatlichkeit, Norderstedt 2008, pp. 19-29.

11 G. Lepan, “Guerre et paix chez Rousseau”, Dix-huitième Siècle 1998, no. 30, pp. 435-456; F. Ramel, J.P. Joubert, Rousseau et les relations internationales, Paris 2000, pp. 20-116; J.F. Thibault, "Les relations internationales et la crise de la pensée politique moderne selon Jean-Jacques Rousseau", Etudes Internationales 37, 2006, no. 2, pp. 217-220. 
nicity, race, etc. The equality of all citizens is transformed into a preference for social homogeneity.

The political doctrine of FN/RN cannot be understood without the abovementioned observations. This party is popularly referred to as 'extreme right' (extrême droite). This term, associated with extremism, is a stereotype that has been adopted even by scholars who are sympathetic to it. ${ }^{12}$ In post-war France, the media and political scientists equate nationalism with the extreme right, without analyzing the entire agenda. ${ }^{13}$ Nationalism alone is considered sufficient to recognize FN/RN as 'extreme right'. ${ }^{14}$ Analysis of the party's program on issues proves that this party is strongly attached to the tradition of revolutionary-democratic patriotism. ${ }^{15} \mathrm{It}$, in fact, defends the tradition of 'sovereignty of the nation' and État-Nation from1789. The politicians of FN/RN interpret the tradition of the French Revolution not as liberal (human rights, emancipation of the individual), but as nationalist, which proclaimed the principle that legitimate power comes from the nation. ${ }^{16}$ This makes it possible for a right-wing party to assimilate the revolutionary État-Nation concept and to consider itself its legitimate successor. FN/RN's demands are directed against the symptoms of disintegration of the État-Nation concept.

\section{The internal sovereignty of État-Nation}

We can observe in France a progressing disintegration of the homogeneous nature of État-Nation. According to FN/RN, this disintegration stems from three sources: disintegration of the community through multiculturalism; progressive ideological pluralism; and oligarchization of political life, undermining the revolutionary postulate of Égalité.

\subsection{Multiculturalism}

France has always been a hospitable country for foreigners: Poles, Italians and Spaniards. In France, there has traditionally existed a conviction that the strength of

12 J. Díaz Nieva, J.L. Orella Martínez, op. cit., p. 21.

13 R. Girardet, Le nationalisme français 1871-1914, Paris 1966, pp. 12-13.

14 A. Chebel d'Appollonia, L'extrême-droite en France. De Maurras à Le Pen, Bruxelles 1996, pp. 44-51, 228-239; X. Ternisien, L'Extrême Droite et l'église, Turnhout 1997, pp. 161-186; R. Remond, Les droites aujourd'hui, Paris 2005, pp. 247-68.

15 G. Birnbaum, Le Front National en politique, Paris 1992, pp. 313-16; D. Heimberger, Der Front National im Elsass. Rechtsextremismus in Frankreich. Eine regionale Wahlanalyse, dissertation, Freiburg University, 2001, pp. 37-39; A. Wielomski, M. Ziętek-Wielomska, The Europe of Nations and its Future. Nationalism, Euroscepticism, Natiocratism, Warszawa 2017, pp. 71-82; A. Wielomski, Nacjonalizm wobec problemu Europy, Warszawa 2018, pp. 177-90.

16 P.A. Taguieff, "Un programme »révolutionnaire«?", [in:] Le Front National à découvert, eds. N. Mayor, P. Perrineau, Paris 1996, pp. 197-200. 
French culture is so great that it can absorb tens and hundreds of thousands of immigrants, whose children will be born French. This situation changed in the sixties with the arrival of economic immigrants from Islamic countries. The religious difference turned out to be difficult to cross in the process of integration. In addition, they live in the compact suburbs of large cities, where they often form the majority. In the area of the homogeneous area of État-Nation, large enclaves of civilization are created, whose inhabitants neither feel French nor speak correct French.

FN/RN's demands regarding foreigners are not directed against all who settle in France, but against Muslim immigrants. FN/RN does not come out against immigrants from the European Union (also from new member states in Eastern Europe), Christian immigrants from Africa nor those Islamic immigrants who were loyal to the French metropolis during the turbulent period of decolonization (harkis from Algeria, who, counting families and descendants, number from 0.8 to 1 million people). FN/RN seeks to remove primarily Muslim economic immigrants from France, namely: 1. persons residing illegally in the country (in this case, it is about strict enforcement of existing law); 2. changes to the jus soli in favor of jus sanguinis, since the existing law automatically grants citizenship to the children of illegal immigrants; 3 . introduce significant impediments to obtaining citizenship (requirements for excellent language skills, permanent employment, ten-year domicile, taking an oath of loyalty to the new homeland); 4. impede the process of several families applying for citizenship; 5. stripping citizenship from immigrants convicted of a common crime in France (this pertains to strict enforcement of already existing law). ${ }^{17}$

The FN/RN does not postulate depriving the citizenship of those immigrants who have already obtained it, with the exception of persons convicted in a court of law. Once again, we have here a line of reasoning taken from Rousseau: those who obtained citizenship are treated as joining the social contract constituting the state. France can no longer exclude them from the contract, except because of their violation of the law, i.e. the rules of the agreement on admission to the political community.

The FN/RN calls for state intervention in the process of locating new citizens in order to liquidate immigrant ghettos on the outskirts of large cities, where crime is extremely high and immigrants live in separation from the native French. Immigrants acquiring citizenship must be mixed up with their surroundings, absorbed by them, so that their children become French by conviction and by culture. Thus, the demands for a radical reduction in the number of immigrants are accompanied by the desire to include those who have already acquired citizenship into the French national community, for their complete assimilation, so that their children differ from French children only by skin color and anthropological features. Race

17300 mesures pour la renaissance de la France. Front National, programme de gouvernement, Saint-Brieuc 1993, pp. 24-50; B. Mégret, L'Alternative national. Les priorités du Front National, Saint-Cloud 1997, pp. 79-98. 
has no meaning for the concept of 'Frenchness'. ${ }^{18}$ A common school, upbringing in the spirit of belonging to the tradition of 'great France' and assimilation of civic values will transform immigrant children into authentic Frenchmen. FN/RN politicians often use the term 'citizenshipness' or 'civic virtues' (civisme) - a member of the nation is he who accepts as his own French civilizational and political values. During the Revolution, members of the nobility and foreigners who accepted the principles of republicanism and national sovereignty would receive certificates of civisme from the government. The fact that they are also mentioned in FN/RN policy papers in relation to immigrants is very characteristic.

\subsection{Internal disintegration of the community}

In the illiberal revolutionary tradition on which $\mathrm{FN} / \mathrm{RN}$ is based, the nation was to be constituted by citizens with a similar level of wealth and similar way of thinking. This is how the heritage of Republican Antiquity was perceived: Athens and Sparta, and especially Rome as described by Titus Livius. ${ }^{19}$ The republican project in France was originally illiberal because it was based on the vision of citizens with a similar culture and views, who were to be instructed in the values of civisme, which were based on ancient tradition, in a 'secular and republican school'. Even critics of republicanism, such as Charles Maurras and Action Française, came from this culture, referring again and again to Greek authors. The uniformity of the intellectual culture, lasting for 200 years, enabled communication between all political currents, despite their differences.

Meanwhile, the contemporary French are increasingly divided into two groups: 'Europeanized', those with liberal and leftist views; and the 'traditional', attached to the État-Nation. Cultural groups with their own identity are emerging, ranging from Catholic traditionalists to sexual minorities, not to mention Muslim suburbs. The French are less and less a homogeneous nation created by the French Revolution, transforming into a multicultural and pluralistic society in which group identity takes precedence in relation to that of national identity. The latter is visibly loosening. This phenomenon is noted not only by opposing nationalists, but also by left-wing authors, who see it as a positive thing. In a word, the homogeneous État-Nation is transforming into a postmodern society. ${ }^{20}$ French Establishment parties consider this phenomenon neutral (center-right) or positive, or leading to emancipation from the traditional way of thinking (left). In this way, the French political elite are moving away from the vision of a homogeneous nation.

18 B. Gollnisch, R. Haddad, La réaction, c'est la vie!, Paris 2003, p. 27.

19 V. Arena, The Roman Republic of Jean-Jacques Rousseau, History of Political Thought 37, 2016, Special Issue, pp. 8-31.

20 Y. Lacoste, Vive la Nation! Destin d'une idée géopolitique, Paris 1997, pp. 166-220. 
Paradoxically, this revolutionary (originally leftist) postulate was adopted by the FN/RN at the turn of the 20th and 21th centuries, which declares the defense of France against ideological pluralism, seeing it as a serious threat to spiritual and intellectual unity. Along the way, this demand undergoes a slight correction in relation to the revolutionary prototype, because in $\mathrm{FN} / \mathrm{RN}$ doctrine, the nation is founded on homogeneous revolutionary tradition, but with a pluralism open to Catholic postulates. It is about recognizing Catholic heritage as a certain foundation of the nation's civilization, but without the postulate of confessionalization of the state and negation of the principle of secularism, ${ }^{21}$ and the undermining of the monopoly of the state schools, in favor of the right of parents to choose a private school (usually a Catholic school in the context of France). The latter would be free of charge, thanks to a 'school voucher' that parents give to the school their child attends. A public subsidy would follow this voucher. ${ }^{22}$ This would undermine the hegemony of state education. There should also be many more hours devoted to classical culture, philosophy, French history and native language classes in school programs. State patronage should favor artists who promote classic French tradition and history, not postmodern art.

\subsection{Oligarchization}

A sense of inequality and alienation between a formally sovereign nation and its political and media elites is spreading throughout Europe. The French see this 'democratic deficit' not only in the EU institutions, but also in their own country; hence, the popularity of attitudes, which in literature are often referred to as 'populist', i.e. a sense of contradiction between the interests of the nation and its traditional beliefs, and the interests of its cosmopolitan elite, proclaiming European integration and supporting international corporations. ${ }^{23}$

$\mathrm{FN} / \mathrm{RN}$ is a nationalist party that defends the tradition of the French Revolution of 1789. By opposing the disintegration of the homogeneous État-Nation, it also opposes the phenomenon of the elite being detached from society because it contradicts the revolutionary idea of Egalité. The authors of the FN 300 mesures pour la renaissance de la France program from 1993 utilize a characteristic language game. When they describe the growing centralism, statism and state socialism in France, they condemn it as 'Jacobinism', thus rejecting left-wing extremism from the revolutionary tradition. When they write about political, financial and media elites in France and Europe, they use the concept of 'feudalism'. The last term in the revolutionary narrative was synonymous with the privilege of the aristocratic

21 J.Y. Le Gallou, "Culture et identité national", [in:] Une âme pour la France, Paris 1988, pp. 45-47; B. Mégret, op. cit., pp. 42-47.

22300 mesures..., pp. 74-77; B. Mégret, op. cit., pp. 118-120.

23 D. Albertazzi, D. McDonnel, Twenty-First Century Populism: The Spectre of Western European Democracy, London 2008, p. 3. 
minority against whom the revolutionary principle of equality of citizens and the sovereignty of the people was addressed, from which Emmanuel-Joseph Sieyès excluded the 'privileged' (privilégés) who did not want to recognize the idea of equality of citizens before the law. ${ }^{24}$ Referring to the vision of the egalitarian nation of Rousseau and Sieyès, the FN/RN excludes from the nation a new class of 'privileged' people in the realities at the turn of $20^{\text {th }}$ and $21^{\text {st }}$ centuries: professional politicians, elite officials from the ENA, journalists from big media, financiers, bankers and owners of transnational corporations. In the name of an egalitarian idea and following Maurras, FN/RN distinguishes the proper French nation (pays réel) from its elites that create an artificial reality (pays légal). ${ }^{25}$ But let us remember that this known oppositional model attributed to Maurras was actually created earlier by Paul Déroulède ${ }^{26}$ - a democratic but anti-parliamentary politician who already at the end of the $19^{\text {th }}$ century placed the idea of the nation's sovereignty in opposition to the rule of parliamentarians and political parties. Utilizing the pays réel-pays légal opposition model, $\mathrm{FN} / \mathrm{RN}$ politicians do not postulate the restoration of the monarchy, like Maurras, but the democratization of the Fifth Republic by frequent appeals to the nation. Therefore, they propose the introduction of an obligatory referendum as soon as a referendum committee gathers a sufficient number of signatures for any citizens' initiative. The nation should make decisions on matters that it considers key: European integration, the death penalty, and immigration. ${ }^{27} \mathrm{FN} / \mathrm{RN}$ politicians are aware that the French pays réel are definitely more conservative, anti-immigrant and Eurosceptic than the political elite. Here, we have another reference to the ideas of Rousseau and Sieyès, i.e. the opposition between volonté générale and the privileged elites. Just as at the end of the eighteenth century, this idea was used against the rule of hereditary aristocracy, so now it has been directed against the rule of political, financial and media elites who rely on democracy, but are in fact fearful of it.

\section{External sovereignty of the État-Nation}

\subsection{From Europe to the nation-state}

$\mathrm{FN} / \mathrm{RN}$ is a party commonly associated with Euroscepticism, and, at the same time, opposed to American domination in the world. However, for many years, this political grouping expressed a different position on these issues. More or less until 1989-1991, the FN was terrified at the prospect of a Warsaw Pact invasion

24 E.J. Sieyès, Qu'est-ce que le Thiers-Etat?, Paris 1789, p. 125.

25 Ch. Maurras, Mes idées politiques, Paris 1968 [1937], p. 71; idem, Dictionnaire politique et critique (complément), vol. 3, Paris 1961-1975, pp. 273-276.

26 P. Déroulède, Oeuvres complètes, vol. 8, Landreville 1995, p. 241.

27300 mesures..., pp. 396-401. 
of Western Europe. Even Gorbachev's Perestroika was treated here as a PR stunt aimed at dulling NATO's vigilance. At that time, the FN supported the strengthening of NATO and argued for a close transatlantic alliance. Fearing the reduction of American troops in Europe, the party called for the creation of a European federation, a 'European state', the creation of European nationalism, constituting the basis for the creation of a joint army, the core of which was to be the merger of the armed forces of France and Germany. ${ }^{28}$

After the fall of the USSR (1991), there occurred a radical rethinking of these views and a return to the theses of Rousseau and French revolutionaries: that a sovereign nation could not be part of external structures in which its sovereignty could be limited. Thus, the growing criticism of the emerging European Union, where the sovereignty of the État-Nation is called into question, since the sovereign nation and its will - expressed by means of laws - is governed by EU legislation. The French courts are ruled by the European Court of Human Rights and the European Court of Justice. ${ }^{29}$ In discussions on further integration, pan-European executive institutions, including the 'president' and 'government' of the European Union, are more and more boldly discussed. Europe is increasingly being discussed not as a confederation of states, but as a multinational 'empire'. ${ }^{30}$ After the Gulf War, FN/RN politicians came to the conclusion that American hegemony also became a threat to sovereign states. ${ }^{31}$

\subsection{European integration and national sovereignty}

The list of FN/RN allegations regarding European integration is long. Their essence is the transfer of sovereignty from État-Nation to the slowly emerging European federal state. FN/RN undermines the basic principles of the European Union:

1. Primacy of Community law over national law. Bruno Mégret points out that France lost its sovereignty on 19 June, 1998, when the French Parliament set new dates for the permitted hunting of ringdoves (a pigeon species). This law was ignored by the courts, which considered it contrary to European regulations regarding hunting dates. ${ }^{32}$ For FN/RN, this is a breakthrough date when acts enacted by

28 B. Mégret, L'Impératif du renouveau. Les enjeux de demain, Paris 1986, pp. 109, 123-125, 140-141; J.M. Le Pen, Europe. Discours et interventions, 1984-1989, Paris 1989, pp. 34-35, 43, $56,63-73,90-91$.

29 G.J. Wąsiewski, „Francuska koncepcja suwerenności i jej ewolucja w procesie integracji europejskiej (na tle orzecznictwa Rady Konstytucyjnej)", [in:] Suwerenność państwa w dobie integracji i globalizacji, eds. S. Jaczyński, A. Wielomski, Siedlce 2007, pp. 187-205.

30 J. Zielonka, Europe as Empire: The Nature of the Enlarged European Union, Oxford 2006; U. Beck, E. Grande, Cosmopolitan Europe, Cambridge 2007.

31 B. Gollnisch, R. Haddad, op. cit., pp. 70-74; J.M. Le Pen, J'ai vu juste!, Saint-Cloud, [n.d.], pp. 64-71.

32 B. Mégret, La Nouvelle Europe. Pour la France et l'Europe des nations, Saint-Cloud 1998, p. 9. 
the État-Nation in the hierarchy of law were found to be lower than EU (external) legislation. The principle of the subordination of national law cannot be accepted. ${ }^{33}$

2. The scope of regulation of European law. Criticism in this regard relates to the scope of intervention (liberal moment). The goal of integration was to create a common free market in Europe, a liberalization beneficial for economic development. Meanwhile, the scope of regulation by the EU institutions is increasing, leading to restrictions on economic freedoms. Regulations flowing from EU institutions constitute $50-80 \%$ of all laws enacted in the Member States. The legislative power of a sovereign nation is becoming increasingly illusory. The European Commission and European Parliament ceased to be subsidiary bodies, usurping sovereign power. ${ }^{34}$

3. The principle of rule by majority vote. FN/RN opposes the majority vote rule. The absolutely sovereign of the État-Nation cannot be overruled and forced to implement the decisions of most states, i.e. external political entities. The ÉtatNation has a monopoly on the definition of national interest. By adopting the principle of majority decision, the European Union ceased to be a confederation of sovereign states, transforming into a federation. Member States not complying with EU law are exposed to political and financial sanctions. In extreme cases, there is a legal possibility to deprive a state of the right to vote, i.e. its political incapacitation. Under EU law, a sovereign nation may be subject to external power directed against it, i.e. tyranny. ${ }^{35}$

4. 'Deficit of democracy'. The European Commission and other EU institutions have become too independent of the signatory states, becoming a body pursuing its own goals. Sovereign nations have lost control of EU bureaucracy. The European Commission is not elected by any sovereign nation, neither French nor 'European'. Its composition is determined in cabinets and lobby rooms, as a result of the arrangements of the strongest member states. This nondemocratic institution imposes its legal acts on sovereign states whose parliamentarians have been elected by the nation. Thus, the sovereignty of the nation becomes a fiction, and power imperceptibly passed into the hands of an informal and cosmopolitan political-managerial oligarchy, which does not answer anyone, into the hands of the 'privileged'. The European Union is not a democratic structure because it has abandoned the very democratic principles to which it appeals so often. ${ }^{36}$

To sum up, the essence of the critique of European integration emerging from the writings of FN/RN has no basis in the - characteristic of the traditional right - critique of democratic axiology. On the contrary, it is a position originating from Rousseau's idea of the people's rule and the sovereignty of the nation of the French revolutionaries of 1789 .

33300 mesures..., pp. 360-63, 401-02; B. Mégret, La Nouvelle Europe..., pp. 31-36.

34 B. Mégret, La Nouvelle Europe..., pp. 51-52, 64, 141-143, 157-161.

35 Ibidem, pp. 54-55, 64-66.

${ }^{36}$ Ibidem, pp. 37-38, 173-176. 


\section{3. 'New Europe' program}

By opposing the federal concept of unification dominating in Europe, the FN/ $\mathrm{RN}$ does not reject the idea of a European confederation, unless it conflicts with the absolute sovereignty of the nation. Bruno Mégret presented the holistic alternative program of New Europe (Nouvelle Europe) in 1998. This work and other documents show that the Europe of Nations is to be based on the following principles: ${ }^{37}$

1. Identity. Every nation has the right to protect its identity, and the right to cultivate the traditional customs and religion of its ancestors. Only countries which are heirs to the European tradition, identified with Greek philosophy, Roman culture and Christianity, will be invited to the confederation. ${ }^{38}$ This excludes the invitation of e.g. Turkey. It also means halting immigration from Islamic countries, because immigrants threaten the civilizational unity of the continent. The new Europe will also defend its identity against the flood of American shoddy and consumerist pop culture. The European Union would be acceptable under certain conditions if its goal was to fight American dominance in the world. Unfortunately, it is only an economic project, a single market, and nothing else joins the continent together.

2. The principle of unanimity. The État-Nation cannot be overruled and forced to comply with the policies imposed on it from the outside, as this would negate the absolute principle of the sovereignty of the nation.

3. Supremacy of national law over European law. A sovereign État-Nation cannot be subject to outside laws.

4. Liquidation of the European Commission. This institution should be transformed into a secretariat for meetings of representatives of sovereign Member States debating common problems.

5. Rebuilding borders. A sovereign nation has the right to decide who it lets in and whom it forbids entry into its territory. This would mean the liquidation of the Schengen area.

6. Restitution of liberal economics. This is to be done by the liquidation of the European Commission, which displays unbridled interventionist tendencies. The new Europe should return to the competition model so that member states wanting to attract capital are forced to liberalize their own economies. Considering that the postulate of economic liberalization is combined in the FN/RN program with the reconstruction of borders and elements of protectionism, this economic program can be described as 'national liberalism'.

The abovementioned demands pave the way for the idea of a new treaty of a Europe of Nations, which should replace those of Maastricht and Lisbon. Its principle would be to replace the integration of all countries with the principle of voluntary cooperation. Member States should be free to participate in the imple-

37300 mesures..., pp. 355-72; B. Mégret, L'Alternative national..., pp. 224-231; B. Mégret, La Nouvelle Europe..., pp. 73-103.

38 B. Mégret, L'Alternative national..., p. 111. 
mentation of individual projects. A project becomes pan-European if all members accept it unanimously. Those who are against it will not participate in it. FN/RN proposed seven treaties for members of the future confederation: 1 . on a customs union; 2. on the common market; 3 . on the common agricultural policy; 4 . on the monetary union; 5. on cultural cooperation; 6 . on the military alliance (in practice, this would mean the liquidation of NATO, which is an instrument of American domination); 7. on the European court of arbitration..$^{39}$ Each country has the right to withdraw from or join any of the pacts at any time. Each state retains the right to withdraw from all seven treaties, which would probably be tantamount to resigning from membership in New Europe. The entry or exit of France from each of the seven treaties requires a referendum. This is the consequence of the fundamental principle that the nation has primary sovereignty.

\subsection{Against globalization and Americanization of the world}

FN/RN's opposition to building a European federation is an aspect of the broader problem of contradictions between État-Nation's Rousseauian vision and globalization, characterized by the disappearance of borders and the weakening of the meaning of the traditional concept of sovereignty. Globalization is criticized here from three positions:

1. Culture. The European Union has been constituted solely to facilitate trade and accelerate economic circulation. A person is not treated here as a Frenchman, a Pole or a German, but as a producer and consumer, hence the principle of supremacy of EU law over national law, as it makes it easier for financiers and corporations to multiply profits at the expense of the sovereignty of Member States. Integration was subordinated to economics. Non-economic spheres were considered insignificant. They were subjected to the principle of relativism and ubiquitous tolerance, so as not to hamper the economy with worldview disputes. Economization is a prerequisite to globalization, i.e. economic, cultural and political subordination to the United States and the Wall Street headquarters of cosmopolitan capital. Globalization is an American vision of the world and man, based on free world trade. FN/RN positions itself in the anti-American narrative characteristic of the French Right. ${ }^{40}$

2. Economics. The FN/RN program is characterized by economic protectionism and is unsympathetic to global free trade. It is characterized by fear of cheap external competition, formerly Anglo-Saxon, and now also from the Far East. New Europe should adopt a protectionist policy and favor its own products at the ex-

${ }^{39}$ Ibidem, pp. 94-95.

40 M. Winock, Nationalisme, antisémitisme et fascisme en France, Paris 1990, pp. 50-82. 
pense of those imported from outside. ${ }^{41}$ The European Union would make sense if it were a counterweight to American domination in the world, but its political elites recognize and accept this hegemony. The European Union is part of a global state project dominated by large American banks and corporations. ${ }^{42}$

3. Politics. In recent years, the FN/RN has witnessed the weakening of US political supremacy, due to the increase in China's economic potential and the rebuilding of Russia's military power. Today, Marine Le Pen proclaims a vision of a multipolar world, ruled jointly by a new 'concert of powers': the United States, Russia, China, France and several other powers. In this project, Europe is treated as a collection of sovereign states, and not one global political entity. ${ }^{43}$

\section{Conclusions}

The purpose of this text was to break with the vision of the FN/RN as a party to the 'extreme right'. That is why we pointed to the links between the main ideas of this party and the French national democratic tradition emerging from the writings of Rousseau, Sieyès and the French Revolution. Paradoxically, although the beginning and tradition of this revolution are still celebrated in France, in fact the political elite and a large part of society have actually rejected its ideals in favor of liberalism, individualism, pluralism and multiculturalism. If we were to refer to the $\mathrm{FN} / \mathrm{RN}$ as a conservative or reactionary party, then we must remember that it does not base itself on the tradition of the pre-revolutionary Catholic monarchy, nor on Action Française-type monarchism, nor on the clericalism of Vichy France. On the contrary, the FN/RN appeals to the tradition of the French Revolution and we believe that this is a completely sincere reference. It is just that this tradition itself has become very 'reactionary' today. Political and ideological processes over the past two hundred years have greatly accelerated and ideas, which in 1789 or 1820 seemed to be revolutionary and devastating, are today perceived as 'far-right' or 'populist'. Of course, FN/RN politicians and journalists also interpret the French Revolution in their own way, pointing to national themes and ideas, and marginalizing liberal ones. However, it is true that for the political elites of modern France, the nationalist themes of the 1789 Revolution have become troublesome, to say the least.

${ }^{41}$ Pour un Nouveau Protectionisme, ed. J.M. Le Pen, Paris 1984, pp. 83-102; J.Y. Le Gallou, “Libre-échangisme dogmatique ou protectionnisme raisonnable?", [in:] Pour un Nouveau Protectionisme, ed. J. Robichez, [n.p., n.d.], pp. 79-88; J.M. Le Pen, 'Pour un protectionnisme de prospérité et d'independance', [in:] Pour un Nouveau..., pp. 121-33.

42 B. Mégret, L'Alternative national..., pp. 140-45; B. Mégret, La troisième voie. Pour un nouvel ordre économique et social, Paris 1997, pp. 57-72, 135-154.

43 “'Prezydent Francji jest tylko wicekanclerzem Niemiec'. Z Marine Le Pen rozmawia Adam Wielomski”, Pro Fide Rege et Lege 75-76, 2015, no. 2, pp. 73-76. 


\section{References}

300 mesures pour la renaissance de la France. Front National, programme de gouvernement, Saint-Brieuc 1993

Albertazzi D., McDonnel D., Twenty-First Century Populism: The Spectre of Western European Democracy, London 2008.

Albertini D., Doucet D., Histoire du Front national, Paris 2014.

Arena V., "The Roman Republic of Jean-Jacques Rousseau”, History of Political Thought 37, 2016, Special Issue.

Beaune C., Naissance de la nation France, Paris 1985.

Beck U., Grande E, Cosmopolitan Europe, Cambridge 2007.

Birnbaum G., Le Front National en politique, Paris 1992.

Brubaker R., Citizenship and Nationhood in France and Germany, Cambridge, MA 1996.

Chebel d'Appollonia A., L'extrême-droite en France. De Maurras à Le Pen, Bruxelles 1996.

Chevallier J.J., "Jean-Jacques Rousseau ou l'absolutisme de la volonté générale", Revue Française de Science Politique 18, 1953, no. 1.

Déroulède P., Oeuvres complètes, vol. 8, Landreville 1995.

Díaz Nieva J., Orella Martínez J.L., De Le Pen a Le Pen. El Front National camino al Elíseo, Madrid 2015.

Le Gallou J.Y., "Culture et identité national”, [in:] Une âme pour la France, Paris 1988.

Le Gallou J.Y., "Libre-échangisme dogmatique ou protectionnisme raisonnable?”, [in:] Pour un Nouveau Protectionisme, ed. J. Robichez, [n.p., n.d.].

Girardet R., Le nationalisme français 1871-1914, Paris 1966.

Girardet R., Nationalismes et Nation, Paris 1996.

Gollnisch B., Haddad R., La réaction, c'est la vie!, Paris 2003.

Guilhaumou J., "Rousseau, citoyenneté, et la Révolution française (1789-1792)”, Etudes JeanJacques Rousseau 5, 1989, no. 3.

Hall A., Naród i państwo w myśli politycznej Charles'a de Gaulle’a, Warszawa 2005.

Heimberger D., Der Front National im Elsass. Rechtsextremismus in Frankreich. Eine regionale Wahlanalyse, dissertation, Freiburg University, 2001.

Kohn H., Prelude to Nation-States. French and German Experiences, 1789-1815, Princeton 1967.

Kutz J.P., Gemeinwille oder Gotteswille? Jean-Jacques Rousseau und Joseph de Maistre über Souveränität und Staatlichkeit, Norderstedt 2008.

Lacoste Y., Vive la Nation! Destin d'une idée géopolitique, Paris 1997.

Lepan G., "Guerre et paix chez Rousseau", Dix-huitième Siècle 1998, no. 30.

Le Pen J.M., À contre flots, Paris 2006.

Le Pen J.M., Europe. Discours et interventions, 1984-1989, Paris 1989.

Le Pen J.M., J'ai vu juste!, Saint-Cloud, [n.d.].

Le Pen J.M., "Pour un protectionnisme de prospérité et d'independance", [in:] Pour un Nouveau

Protectionisme, ed. Jacques Robichez [n.p., n.d.].

Martin M.M., Histoire de l'unité française, Paris 1957.

Maurras Ch., Dictionnaire politique et critique (complément), vol. 3, Paris 1961-75.

Maurras Ch., Mes idées politiques, Paris 1968 [1937].

Mégret B., L'Alternative national. Les priorités du Front National, Saint-Cloud 1997.

Mégret B., L'Impératif du renouveau. Les enjeux de demain, Paris 1986.

Mégret B., La Nouvelle Europe. Pour la France et l'Europe des nations, Saint-Cloud 1998.

Mégret B., La troisième voie. Pour un nouvel ordre économique et social, Paris 1997.

Neumann M., "Rousseau et le nationalisme", [in:] Jean-Jacques Rousseau. Politique et Nation, ed. R. Thiéry, Paris 2001. 
““Oskarżenia o faszyzm to oczywiście tradycyjny repertuar lewicy'. Z Bernardem Anthonym rozmawia Adam Wielomski”, Pro Fide, Rege et Lege 92, 2008, no. 1.

Palacios X., "Le concept de Nation chez Jean-Jacques", [in:] Jean-Jacques Rousseau. Politique et Nation, ed. R. Thiéry, Paris 2001.

Plumyène J., Les nations romantiques. Histoire du nationalisme. Le XIXe siècle, Paris 1979.

“'Prezydent Francji jest tylko wicekanclerzem Niemiec'. Z Marine Le Pen rozmawia Adam Wielomski", Pro Fide Rege et Lege 75-76, 2015, no. 2

Pour un Nouveau Protectionisme, ed. J.-M. Le Pen, Paris 1984.

Ramel F., Joubert J.P., Rousseau et les relations internationales, Paris 2000.

Remond R., Les droites aujourd'hui, Paris 2005.

Riva J., La difficile cohabitation Etats - Nations/Europe, Paris 2013.

Rousseau J.J., Du contrat social, Paris 2008 [1762].

Sieyès E.J., Qu'est-ce que le Thiers-Etat?, Paris 1789.

Taguieff P., "Un programme »révolutionnaire«?", [in:] Le Front National à découvert, eds. N. Mayor, P. Perrineau, Paris 1996.

Ternisien X., L'Extrême Droite et l'église, Turnhout 1997.

Thibault J.F., "Les relations internationales et la crise de la pensée politique moderne selon Jean-Jacques Rousseau", Etudes Internationales 37, 2006, no. 2.

Vernant J., "Le Général de Gaulle et la politique extérieure", Politique Étrangère 35, 1970, no. 6.

Viguerie J. de, Les deux patries. Essai historique sur l'idée patrie en France, Paris 2003.

Wąsiewski G.J., "Francuska koncepcja suwerenności i jej ewolucja w procesie integracji europejskiej (na tle orzecznictwa Rady Konstytucyjnej)", [in:] Suwerenność państwa w dobie integracji i globalizacji, eds. S. Jaczyński, A. Wielomski, Siedlce 2007.

Wielomski A., "État-Nation. O specyfice francuskiego rozumienia narodu", Pro Fide Rege et Lege 79,2018 , no. 1.

Wielomski A., Nacjonalizm francuski 1886-1940. Geneza, przemiany i istota filozofii politycznej, Warszawa 2007.

Wielomski A., Nacjonalizm wobec problemu Europy, Warszawa 2018.

Wielomski A., Ziętek-Wielomska M., The Europe of Nations and its Future. Nationalism, Euroscepticism, Natiocratism, Warszawa 2017.

Winock M., Nationalisme, antisémitisme et fascisme en France, Paris 1990.

Zielonka J., Europe as Empire: The Nature of the Enlarged European Union, Oxford 2006.

Studia nad Autorytaryzmem i Totalitaryzmem 43, nr 1, 2021

(C) for this edition by CNS 